Acta Crystallographica Section D

Biological Crystallography

ISSN 0907-4449

\section{Sheng-Xue Xie, ${ }^{a}$ Wei-Jun Huang, ${ }^{b}$ Ze-Qiang Ma, ${ }^{\text {a Min }}$ Huang, ${ }^{a}$ Robert P. Hanzlik ${ }^{\mathrm{C}}$ and Qi-Zhuang $\mathrm{Ye}^{\mathrm{a}, \mathrm{c} *}$}

aHigh Throughput Screening Laboratory, University of Kansas, Lawrence, Kansas 66045, USA, 'b Protein Structure Laboratory, University of Kansas, Lawrence, Kansas 66045, USA, and c Department of Medicinal Chemistry, University of Kansas, Lawrence, Kansas 66045, USA

Correspondence e-mail: qye@ku.edu
(C) 2006 International Union of Crystallography Printed in Denmark - all rights reserved

\title{
Structural analysis of metalloform-selective inhibition of methionine aminopeptidase
}

One of the challenges in the development of methionine aminopeptidase (MetAP) inhibitors as antibacterial and anticancer agents is to define the metal ion actually used by MetAP in vivo and to discover MetAP inhibitors that can inhibit the metalloform that is relevant in vivo. Two distinct classes of novel nonpeptidic MetAP inhibitors that are not only potent but also highly selective for either the $\mathrm{Mn}^{\mathrm{II}}$ or $\mathrm{Co}^{\mathrm{II}}$ form have been identified. Three crystal structures of Escherichia coli MetAP complexed with the metalloformselective inhibitors 5-(2,5-dichlorophenyl)furan-2-carboxylic acid (2), 5-[2-(trifluoromethyl)phenyl]furan-2-carboxylic acid (3) and $N$-cyclopentyl- $N$-(thiazol-2-yl)oxalamide (4) have been solved and analysis of these structures has revealed the structural basis for their metalloform-selective inhibition. The $\mathrm{Mn}^{\mathrm{II}}$-form selective inhibitors (2) and (3) both use their carboxylate group to coordinate with the two $\mathrm{Mn}^{\mathrm{II}}$ ions at the dinuclear metal site and both adopt a non-coplanar conformation for the two aromatic rings. The unique coordination geometry of these inhibitors may determine their $\mathrm{Mn}^{\mathrm{II}}$-form selectivity. In contrast, the $\mathrm{Co}^{\mathrm{II}}$-form selective inhibitor (4) recruits an unexpected third metal ion, forming a trimetallic enzyme-metal-inhibitor complex. Thus, an important factor in the selectivity of (4) for the $\mathrm{Co}^{\mathrm{II}}$ form may be a consequence of a greater preference for a softer $\mathrm{N}, \mathrm{O}$-donor ligand for the softer $\mathrm{Co}^{\text {II }}$.

\section{Introduction}

Methionine aminopeptidase (MetAP) removes the N-terminal methionine residue from nascent proteins in all cells (Bradshaw et al., 1998). Prokaryotic cells express only one MetAP, which has been shown to be essential by gene deletion from Escherichia coli (Chang et al., 1989) and Salmonella typhimurium (Miller et al., 1989). MetAP is therefore a potential target for the development of novel broad-spectrum antibacterial agents (Vaughan et al., 2002). Eukaryotic cells have two types of MetAP (type I and type II; Arfin et al., 1995). The anti-angiogenic compounds fumagillin, TNP-470 and ovalicin are potent inhibitors of human type II MetAP (Griffith et al., 1997, 1998; Sin et al., 1997), while the antiproliferative bengamides inhibit both types of human MetAP (Towbin et al., 2003), suggesting that the human MetAPs may also serve as targets for the development of new anticancer agents.

MetAP was initially characterized as a $\mathrm{Co}^{\mathrm{II}}$ enzyme because of the reproducible activation of the apoenzyme by $\mathrm{Co}^{\mathrm{II}}$ (Roderick \& Matthews, 1993; Arfin et al., 1995). Early X-ray structures of MetAPs with or without a ligand bound (Lowther \& Matthews, 2000) all show a dinuclear metal site that is formed by five conserved residues Asp97, Asp108, His171, Glu204 and Glu235 (E. coli MetAP numbering) and
Received 13 November 2005 Accepted 31 January 2006

PDB References: methionine aminopeptidase, complex with 5-(2,5-dichlorophenyl)furan-2-carboxylic acid, 2evm, r2evmsf; complex with 5-[2-(trifluoromethyl)phenyl]furan-2-carboxylic acid, 2evc, r2evcsf; complex with $\mathrm{N}$-cyclopentyl-N-(thiazol2-yl)oxalamide, 2evo, r2evosf. 
filled with two $\mathrm{Co}^{\mathrm{II}}$ ions. However, other divalent metals such as $\mathrm{Mn}^{\mathrm{II}}, \mathrm{Ni}^{\mathrm{II}}, \mathrm{Zn}^{\mathrm{II}}$ and $\mathrm{Fe}^{\mathrm{II}}$ have also been shown to activate the enzyme in vitro (Li et al., 2003; D'Souza \& Holz, 1999). It is not known which metalloforms of MetAP are the most important in vivo, but speculation has favored the $\mathrm{Fe}^{\mathrm{II}}, \mathrm{Zn}^{\mathrm{II}}$ or $\mathrm{Mn}^{\mathrm{II}}$ forms for this role (Walker \& Bradshaw, 1998; D'Souza \& Holz, 1999; Wang et al., 2003). Most MetAP inhibitors were discovered by screening against the $\mathrm{Co}^{\mathrm{II}}$ form of the enzyme in vitro, but potent inhibition of this metalloform has not translated into effective antibacterial (Oefner et al., 2003; Schiffmann et al., 2005) or anti-angiogenic (Garrabrant et al., 2004) activity. We have shown previously that inhibitors of the $\mathrm{Co}^{\mathrm{II}}$ form of MetAP do not necessarily inhibit other metalloforms (Li et al., 2003; Ye et al., 2004). Thus, although there are many reasons that an in vitro active compound may be inactive in vivo, such as absorption, metabolism etc., one of the reasons for the apparent lack of antibacterial and anti-angiogenic activities may be a disparity between the metalloform tested in vitro and that which is important in vivo. Clearly, in order to design MetAP inhibitors as antibacterial and anticancer agents, it is essential to know which metalloforms of MetAP are relevant in vivo and to identify appropriate inhibitors for them.

By screening a diverse chemical library of small organic compounds we have identified two distinct classes of novel nonpeptidic MetAP inhibitors: each has a unique structural scaffold and each comprises several potent inhibitors highly selective for either the $\mathrm{Mn}^{\mathrm{II}}$ or the $\mathrm{Co}^{\mathrm{II}}$ form of $E$. coli MetAP (Ye et al., 2004). The typical $\mathrm{Mn}^{\mathrm{II}}$-form selective inhibitor (1) (Fig. 1) inhibits the $\mathrm{Co}^{\mathrm{II}}, \mathrm{Mn}^{\mathrm{II}}, \mathrm{Ni}^{\mathrm{II}}$ and $\mathrm{Fe}^{\mathrm{II}}$ forms of $E$. coli MetAP with $\mathrm{IC}_{50}$ values of $154,0.24,>200$ and $182 \mu \mathrm{M}$, respectively, while the typical $\mathrm{Co}^{\mathrm{II}}$-form selective inhibitor (4) (Fig. 1) inhibits the four metalloforms with $\mathrm{IC}_{50}$ values of $0.067,53,1.0$ and $46 \mu M$, respectively. The $\mathrm{Mn}^{\mathrm{II}}$-form selective inhibitor (1) was crystallized with the $\mathrm{Mn}^{\mathrm{II}}$ form of $E$. coli MetAP; the X-ray structure showed that this inhibitor fits into a hydrophobic pocket with its carboxylate group coordinating with both $\mathrm{Mn}^{\mathrm{II}}$ ions at the dinuclear metal site (Ye et al., 2004). To determine whether the binding mode of (1) to $\mathrm{Mn}^{\mathrm{II}}$-MetAP is general and to help elucidate the chemical basis for metalloform-selective MetAP inhibition in greater detail, we have now carried out structural studies of E. coli MetAP in complex with the additional metalloform-selective inhibitors. Here, we report two new X-ray crystal structures of the $\mathrm{Mn}^{\mathrm{II}}$ form of E. coli MetAP and one new structure of the $\mathrm{Co}^{\mathrm{II}}$ form, each complexed with a different metalloform-selective inhibitor [(2), (3) and (4)]. Analysis of these complexes provides insight into important structural features of the ligands that are important for metalloform-selective inhibition.

\section{Materials and methods}

\subsection{Preparation of the protein and compounds}

The recombinant E. coli MetAP was purified as an apoenzyme (Li et al., 2003). Compounds (1)-(4) were purchased from ChemBridge (San Diego, CA, USA) and characterized by ${ }^{1} \mathrm{H}$ and ${ }^{13} \mathrm{C}$ NMR and high-resolution mass spectrometry. Their inhibitory activities on the $\mathrm{Co}^{\mathrm{II}}, \mathrm{Mn}^{\mathrm{II}}, \mathrm{Ni}^{\mathrm{II}}$ and $\mathrm{Fe}^{\mathrm{II}}$ forms of E. coli MetAP have been described previously (Huang et al., 2005; Ye et al., 2004). Compounds (2) and (3) inhibited the $\mathrm{Mn}^{\mathrm{II}}$ form with $\mathrm{IC}_{50}$ values of 0.693 and $0.290 \mu M$, respectively.

\subsection{Crystallization conditions}

Initial crystallization conditions were determined using Crystal Screen and Index HT kits in 96-well sitting-drop plates (Hampton Research) at room temperature. Final crystals of the enzyme-inhibitor complexes were obtained independently by the hanging-drop vapour-diffusion method at 291-293 K. Inhibitors (200 $\mathrm{m} M$ in DMSO) were added to concentrated apoenzyme $\left(12 \mathrm{mg} \mathrm{ml}^{-1}, 0.4 \mathrm{mM}\right)$ in $10 \mathrm{mM}$ MOPS pH 7.0 at an inhibitor:apoenzyme concentration ratio of 5:1. Hanging drops contained $3 \mu$ protein solution mixed with $3 \mu \mathrm{l}$ reservoir solution. The reservoir solution consisted of $10-15 \%$ PEG 20 000, 0.1 $M$ MES pH 6.5 and $2 \mathrm{mM} \mathrm{MnCl}_{2}$ for compounds (2) and (3) or 33\% PEG 3350, $0.1 \mathrm{M}$ Bis-Tris pH 6.5, $0.2 \mathrm{M}$ $\mathrm{NH}_{4} \mathrm{OAc}$ and $1.2 \mathrm{mM} \mathrm{CoCl} 2$ for compound (4).

\subsection{Data collection and structural refinement}

Crystals were mounted on an R-AXIS IV imaging-plate detector with a Rigaku rotating-anode generator operated at $50 \mathrm{kV}$ and $100 \mathrm{~mA}$. Images were collected over $180^{\circ}$ in $0.5^{\circ}$ increments at $100 \mathrm{~K}$. Data for these structures were processed with the XDS package (Kabsch, 1993). Structural solutions were achieved using CCP4 (Collaborative Computational Project, Number 4, 1994). Structures were solved with the program AMoRe using an available E. coli MetAP structure (PDB code 2mat; Lowther, Orville et al., 1999) as the search model. Model building was carried out using $O$ (Jones et al., 1991) and crystallographic refinement was performed using

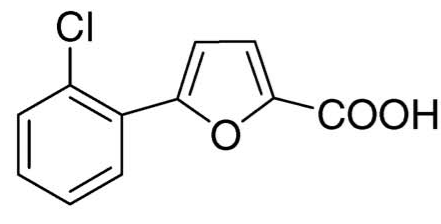

(1)

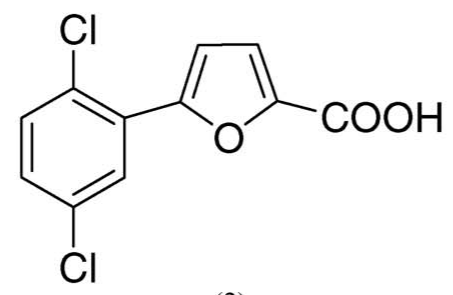

(2)<smiles>O=C(O)c1ccc(-c2ccccc2C(F)(F)F)o1</smiles>

(3)

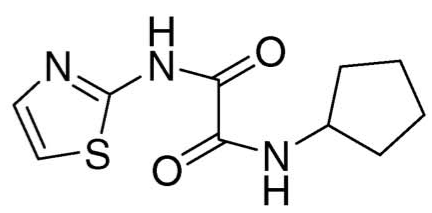

(4)

Figure 1

Structures of the inhibitors used for crystallization and structure solution. Inhibitors (1), (2) and (3) are $\mathrm{Mn}^{\mathrm{II}}$-form selective, while inhibitor (4) is Co ${ }^{\mathrm{II}}$ form selective. 
CNS (Brünger et al., 1998). The refinements were monitored with the free $R$ factor throughout the whole refinement process, with $5 \%$ of the total number of reflections set aside. The initial crystallographic $R$ factors were around $35 \%$ and the refinement process included simulated annealing to a starting temperature of $4000 \mathrm{~K}$, positional refinement, individual $B$-factor refinement and addition of water molecules. The inhibitors were modeled in using $O$ according to the electron densities shown in $2 F_{\text {obs }}-F_{\text {calc }}$ and $F_{\text {obs }}-F_{\text {calc }}$ maps. These electron-density maps were examined with different contour levels. The $2 F_{\text {obs }}-F_{\text {calc }}$ map was contoured around 1.0 , while the $F_{\text {obs }}-F_{\text {calc }}$ map was contoured at around 3.0 and around -3.0. The inhibitors were modelled considering the expected stereochemistry deduced from small-molecule structures. The models were found to fit the electron-density maps superbly. A refinement library has been constructed for this stereochemistry to restrain the refinement with $C N S$. Model building and crystallographic refinement was performed iteratively. When the inhibitor model was complete, it was included in the refinement with the restraint of the above-mentioned stereochemical library. The free $R$ factor continued to fall through several further rounds of refinements without simulated annealing. Final coordinates were analyzed using PROCHECK (Laskowski et al., 1993). The resulting electrondensity maps showed clear densities for most of the atoms except for a few side chains on the molecular surface. It should be noted that there are two protein molecules in the $\mathrm{Co}^{\mathrm{II}}$ complex structure with inhibitor (4), which has not been reported for previous structures of E. coli MetAP. The two molecules were refined independently. Overlay of the two molecules showed no significant differences except for a few surface side chains. Atomic coordinates were examined and superimposed with PyMOL (DeLano, 2002). All drawings for protein structure in the figures were generated using PyMOL.

\section{Results}

\subsection{Overall structure of $E$. coli MetAP in the Mn" and Co" forms complexed with the metalloform-selective inhibitors}

The crystals generated by the hanging-drop method consistently produced high-quality diffraction data for structural solution to resolutions of 1.6-1.7 $\AA$ (Table 1). All three new structures have the typical 'pitta-bread' fold found in other MetAPs with a single molecule of inhibitor bound (Fig. 2). The two structures in the $\mathrm{Mn}^{\mathrm{II}}$ form with $\mathrm{Mn}^{\mathrm{II}}$-form selective inhibitors (2) and (3) contain two $\mathrm{Mn}^{\mathrm{II}}$ ions at the dinuclear metal site (Fig. 3a). In contrast, the $\mathrm{Co}^{\mathrm{II}}$-form structure with the $\mathrm{Co}^{\mathrm{II}}$-form selective inhibitor (4) contains a third $\mathrm{Co}^{\mathrm{II}}$ ion in addition to the two $\mathrm{Co}^{\mathrm{II}}$ ions at the normal dinuclear site (Fig. 3b). Other than the difference in number of metal ions at the substrate- and inhibitor-binding pocket, the structures of the enzyme per se are very similar in the $\mathrm{Mn}^{\mathrm{II}}$ form and in the $\mathrm{Co}^{\mathrm{II}}$ form. The structures were aligned by minimizing the root-mean-square deviation (r.m.s.d.) between the protein backbone atoms. The r.m.s.d. is $0.104 \AA$ between the two $\mathrm{Mn}^{\mathrm{II}}$-form complexes with (2) and (3). The r.m.s.d.
Table 1

X-ray data-collection and refinement statistics.

Values given in parentheses correspond to the outer shell of data.

\begin{tabular}{llll}
\hline Inhibitor & $(2)$ & $(3)$ & $(4)$ \\
\hline Inhibitor code & FC2 & FC3 & CT0 \\
PDB code & $2 \mathrm{evm}$ & $2 \mathrm{evc}$ & $2 \mathrm{evo}$ \\
Metal ion & $\mathrm{Mn}^{\mathrm{II}}$ & $\mathrm{Mn}^{\mathrm{II}}$ & $\mathrm{Co}$ \\
Space group & $P 2_{1}$ & $P 2_{1}$ & $P 2_{1}$ \\
Unit-cell parameters & & & \\
$a(\AA)$ & 37.8 & 37.8 & 49.2 \\
$b(\AA)$ & 60.2 & 60.2 & 63.4 \\
$c(\AA)$ & 50.4 & 50.4 & 75.3 \\
$\beta\left({ }^{\circ}\right)$ & 104.5 & 104.5 & 108.5 \\
X-ray data collection & & & \\
Resolution range $(\AA)$ & $50-1.7(1.8-1.7)$ & $50-1.6(1.7-1.6)$ & $50-1.7(1.8-1.7)$ \\
Collected reflections & 84667 & 102291 & 161123 \\
Unique reflections & 23634 & 27140 & 43944 \\
Completeness $(\%)$ & $98(96)$ & $93(90)$ & $92(88)$ \\
$I / \sigma(I)$ & $23.3(14.1)$ & $25.6(12.3)$ & $20.2(7.0)$ \\
$R_{\text {merge }}(\%)$ & $2.8(6.4)$ & $2.7(7.1)$ & $4.6(16.1)$ \\
Refinement statistics & & & \\
$R(\%)$ & 21.5 & 21.0 & 21.3 \\
$R_{\text {free }}(\%)$ & 24.8 & 22.9 & 24.1 \\
R.m.s.d. bonds $(\AA)$ & 0.005 & 0.005 & 0.005 \\
R.m.s.d. angles $\left({ }^{\circ}\right)$ & 1.340 & 1.330 & 1.350 \\
No. of solvent molecules 180 & 175 & 271 \\
$\langle B\rangle$ enzyme $\left(\AA^{2}\right)$ & 17.7 & 18.0 & 14.4 \\
$\langle B\rangle$ inhibitor $\left(\AA^{2}\right)$ & 11.9 & 16.8 & 21.0 \\
$\langle B\rangle$ water $\left(\AA^{2}\right)$ & 24.7 & 26.0 & 19.6 \\
\hline
\end{tabular}

differences between the $\mathrm{Mn}^{\mathrm{II}}$-form enzymes and the $\mathrm{Co}^{\mathrm{II}}$-form enzyme were slightly larger at 0.277 and $0.299 \AA$.

\subsection{Binding of $M n^{\prime \prime}$-form selective inhibitors (2) and (3) to the $\mathrm{Mn}$ " form of MetAP}

Common features of the $\mathrm{Mn}^{\mathrm{II}}$-form selective inhibitors (2) and (3) bound to E. coli MetAP are that both use their carboxylate group to coordinate with the two $\mathrm{Mn}^{\mathrm{II}}$ ions at the dinuclear metal site and both adopt a non-coplanar or twisted conformation for the two aromatic rings (Fig. 3a), consistent with our previously reported structure of $E$. coli MetAP complexed with (1) (Ye et al., 2004). The twisted conformation found in all of the $\mathrm{Mn}^{\mathrm{II}}$-form selective inhibitors (1)-(3) is in agreement with the requirement of a small hydrophobic orthosubstitution on the phenyl ring for inhibitory activity (Ye et al., 2004; Huang et al., 2005). Recognizing this requirement will be important in the design of future inhibitors. It is well known that most ortho-substituted biphenyl derivatives show a twisted conformation. The average twist angle for 2-fluoro-, 2-chloro- and 2-bromobiphenyl derivatives in the Cambridge Structural Database is 47,53 and $61^{\circ}$, respectively (Leroux, 2004). This twisting is usually explained in terms of repulsion between ortho $\mathrm{H}$ atoms or substituents in the planar conformation. In phenylfurans such as (1)-(3), these steric interactions would be expected to be slightly less than in biphenyls. This is in accord with the lesser twist angles observed in the MetAP complexes of (1)-(3), which are $41.5^{\circ}$ for (1), $32.0^{\circ}$ for (2) and $52.9^{\circ}$ for (3), suggesting that in general the phenylfuran-based inhibitors dock into the active site in a conformation that may correspond to a minimum-energy solution 


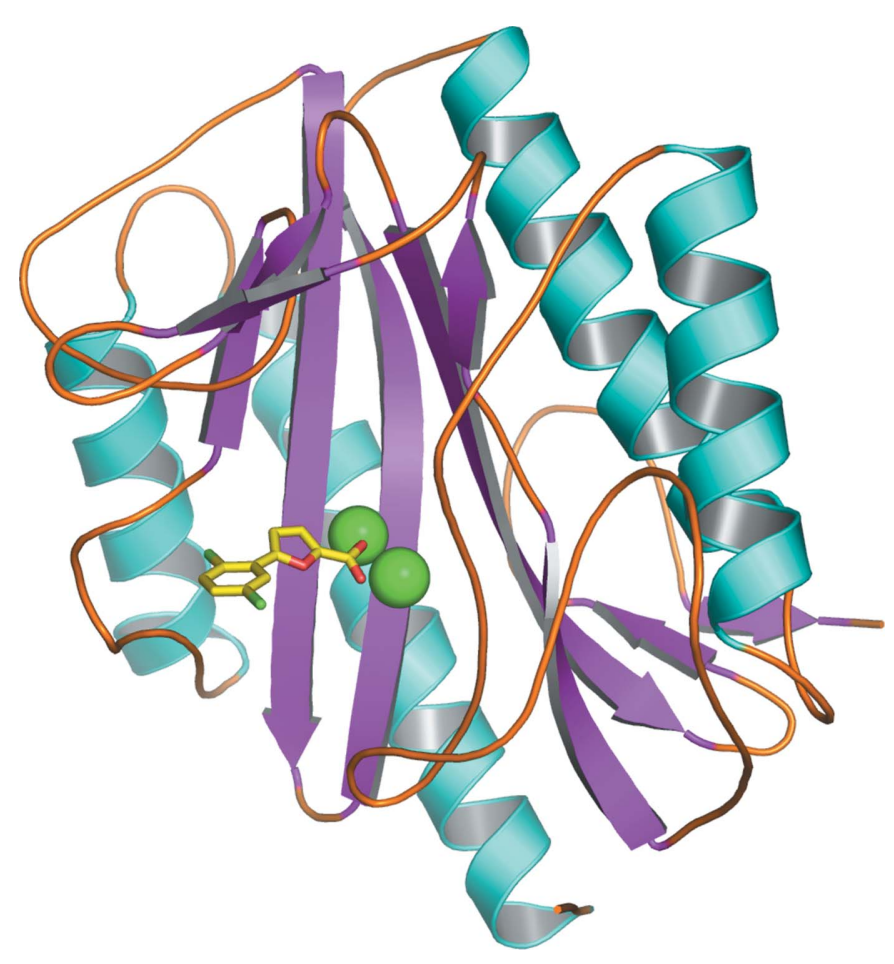

Figure 2

Overall structure of E. coli MetAP complexed with (2) as a ribbon drawing. $\mathrm{Mn}^{\mathrm{II}}$ ions are shown as two green spheres and the inhibitor is shown as in stick representation (carbon, yellow; oxygen, red; chlorine, green). Secondary structures are colored cyan for $\alpha$-helices, magenta for $\beta$-sheets and orange for loops. conformation. This in turn would enhance their binding by decreasing the fraction of binding energy that would be 'wasted' distorting the molecule into a less-favorable conformation in the bound state. Adoption of this conformation is further enforced by binding of the required small hydrophobic ortho-substituents in a small cavity at the bottom of the main hydrophobic binding pocket.

\subsection{The metal site in the $\mathrm{Mn}^{\prime \prime}$-form enzymes with an inhibitor bound}

The dinuclear metal site in the $\mathrm{Mn}^{\mathrm{II}}$-form enzymes is similar to those in the $\mathrm{Co}^{\mathrm{II}}$ form reported by Lowther \& Matthews (2000) in terms of the conserved residues for ligation to the metal ions (Figs. $4 a$ and $4 b$ ). The inhibitors use their carboxyl groups to form a bidentate ligation to the $\mathrm{Mn}^{\mathrm{II}}$ ion designated Mn1; this metal has been suggested to bind with high affinity and to be essential for catalysis (D'Souza et al., 2000). One of the two carboxylate $\mathrm{O}$ atoms of the inhibitor also ligates to the other $\mathrm{Mn}^{\mathrm{II}}$ (designated $\mathrm{Mn} 2$ ). A strictly conserved water molecule (w5) found in both the $\mathrm{Mn}^{\mathrm{II}}$-form structures is also coordinated to $\mathrm{Mn} 2$. Thus, both $\mathrm{Mn}^{\mathrm{II}}$ ions are hexacoordinate with octahedral geometry. The peptidic inhibitor AHHpAAla-Leu-Val-Phe-OMe was developed as a presumed transition-state analog inhibitor of MetAP [AHHpA is (3R)-amino(2S)-hydroxyheptanoic acid] (Keding et al., 1998) and its complex with the $\mathrm{Co}^{\mathrm{II}}$ form of $E$. coli MetAP was described in Lowther, Orville et al. (1999). When this structure is superimposed with our structures, the $\mathrm{O}$ atoms from the hydroxyl and carbonyl groups in the AHHpA moiety occupy the same

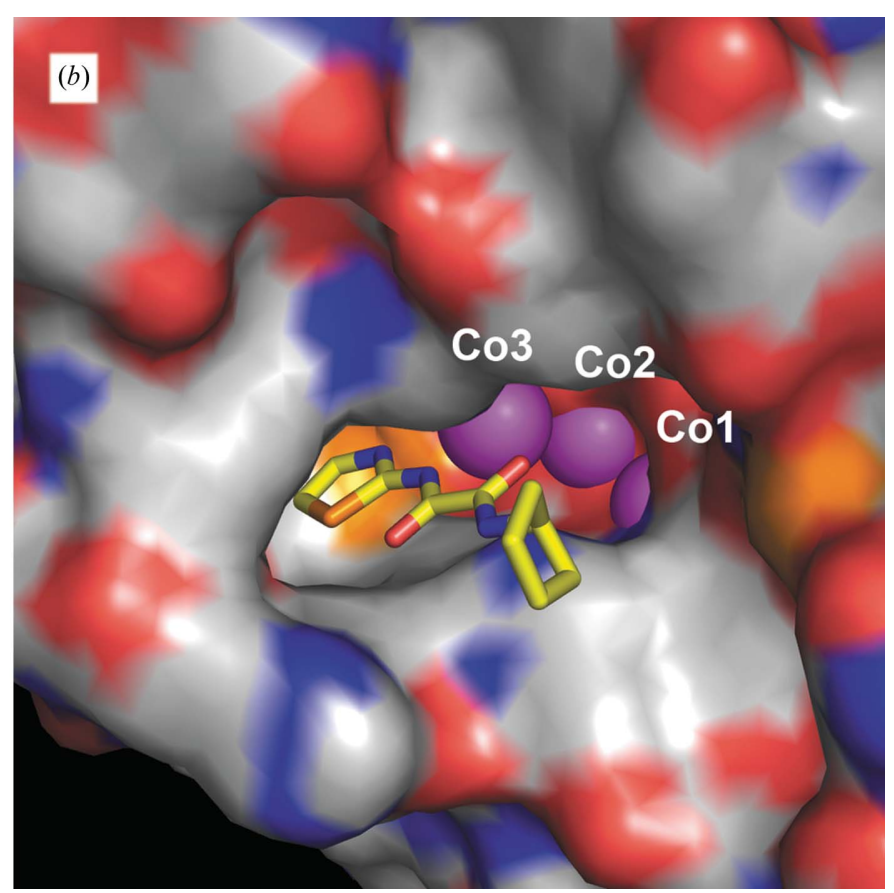

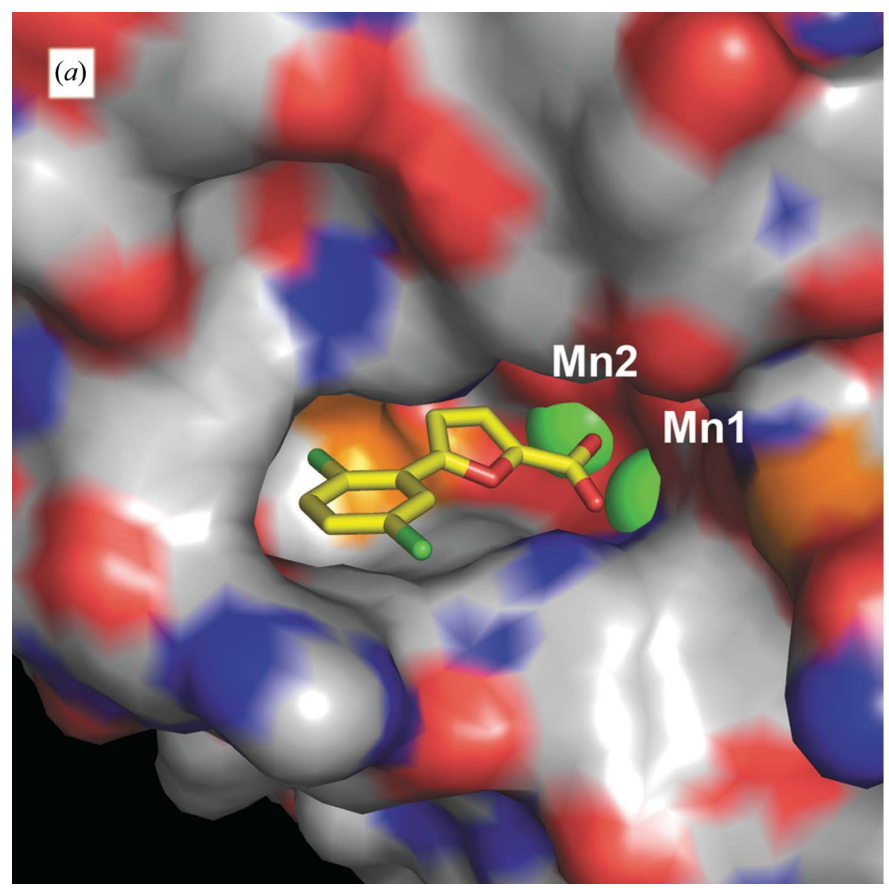

Figure 3

Close-up views of inhibitors (2) and (4) bound at the active-site pocket of E. coli MetAP. (a) The ${ }^{\mathrm{Mn}}{ }^{\mathrm{II}}$-form selective inhibitor (2) bound to the Mn ${ }^{\mathrm{II}}$ form enzyme and $(b)$ the $\mathrm{Co}^{\mathrm{II}}$-form selective inhibitor (4) bound to the $\mathrm{Co}^{\mathrm{II}}$-form enzyme. Two $\mathrm{Mn}^{\mathrm{II}}$ ions are shown as green spheres in $(a)$ and three $\mathrm{Co}^{\mathrm{II}}$ ions are shown as magenta spheres in $(b)$. The inhibitors are shown in stick representation (oxygen, red; nitrogen, blue; chlorine, green; sulfur, orange; carbon, yellow). Protein residues are shown as a solid surface (carbon, grey). 
positions as the two carboxyl $\mathrm{O}$ atoms of our furan-based $\mathrm{Mn}^{\mathrm{II}}$-form selective inhibitors and the $\mathrm{N}$ atom from the amino group of the AHHpA moiety takes up the position of the conserved water molecule (w5) in our structures. picolinamidothiazole in complex with $\mathrm{Co}^{\mathrm{II}}$-MetAP (Schiffmann et al., 2005) and those reported by us recently for a quinolinyl sulfonamide in complex with the $\mathrm{Mn}^{\mathrm{II}}$ and $\mathrm{Co}^{\mathrm{II}}$ forms of E. coli MetAP (Huang et al., 2006). In addition to the

\subsection{Binding of the Co"-form selective inhibitor (4) to the Co" form of MetAP and the metal site in the Co"-form complex}

Compound (4) inhibits the $\mathrm{Co}^{\mathrm{II}}$ form of E. coli MetAP both potently and selectively (Ye et al., 2004). The binding mode of this inhibitor at the active-site pocket has now been revealed by the X-ray structure with inhibitor (4) bound (Figs. $3 b$ and 4c). Surprisingly, inhibitor (4) makes no direct interaction with either of the $\mathrm{Co}^{\mathrm{II}}$ ions at the usual dinuclear metal site ( $\mathrm{Co} 1$ and $\mathrm{Co} 2)$. Instead, its oxalamide core acts as a bidentate N,O-donor ligand toward an unexpected third $\mathrm{Co}^{\mathrm{II}}$ ion $(\mathrm{Co} 3)$ situated not far from $\mathrm{Co} 1$ and $\mathrm{Co} 2 . \mathrm{Co} 3$ is clearly octahedral, with two waters (w1 and w2) trans to the N,O-donor (4) in the meridional plane. One of the apical ligands is an imidazole nitrogen furnished by the side chain of His79. This is the only direct interaction between $\mathrm{Co} 3$ and the enzyme, which probably explains why trimetallic forms of the enzyme are unknown in the absence of an auxiliary metal-coordinating ligand such as (4). The second apical ligand is a water molecule (w3). $\mathrm{Co} 1$ and $\mathrm{Co} 2$ at the typical dinuclear site are coordinated in the usual way. In crystal structures of other MetAPs in the $\mathrm{Co}^{\mathrm{II}}$ form with various ligands, $\mathrm{Co} 1$ and $\mathrm{Co} 2$ can be either pentacoordinate or hexacoordinate (Lowther \& Matthews, 2000). These two $\mathrm{Co}^{\mathrm{II}}$ ions share two $\mu$-carboxylato ligands furnished by residues Asp108 and Glu235 and a $\mu$-aquo ligand (w4) that can be replaced by a donor $\mathrm{O}$ atom of substrates or inhibitors. It is interesting to note that the water molecule w3 interacts simultaneously with $\mathrm{Co} 3$, an imidazole nitrogen from the side chain of His178 and two other water molecules (w4 and w5) that are coordinated to $\mathrm{Co} 1$ and $\mathrm{Co}$. These hydrogen-bonding and ionic (coordination) interactions in this extended array obviously reinforce one another, which is likely to contribute to the overall stability of the complex and to the high affinity of inhibitor (4) for the $\mathrm{Co}^{\mathrm{II}}$ form of the enzyme. This mode of binding of a third $\mathrm{Co}^{\mathrm{II}}$ ion and the extended network it engages in are similar to those reported for thiabendazole and 2-

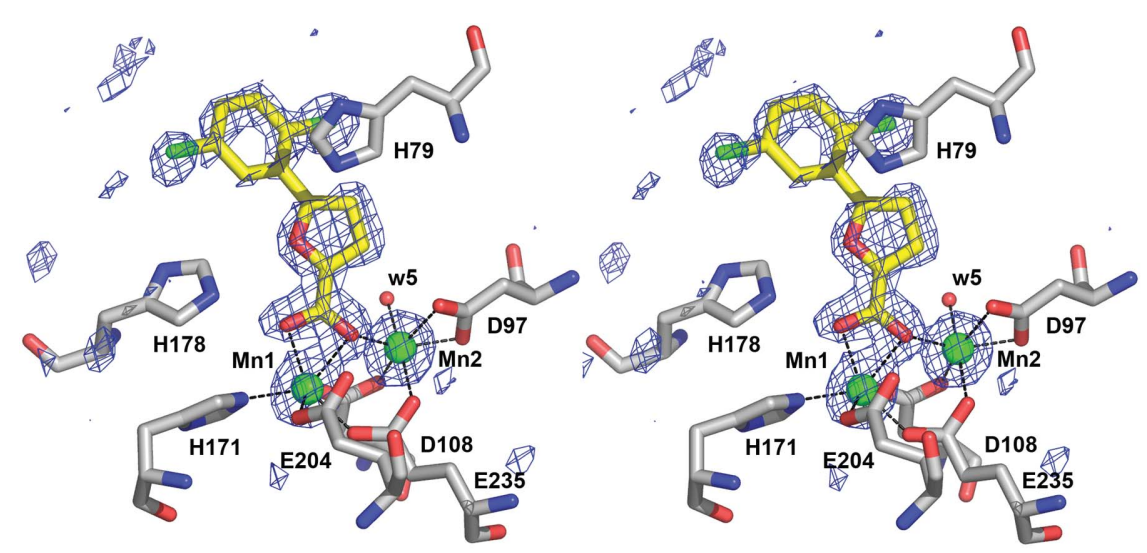

(a)

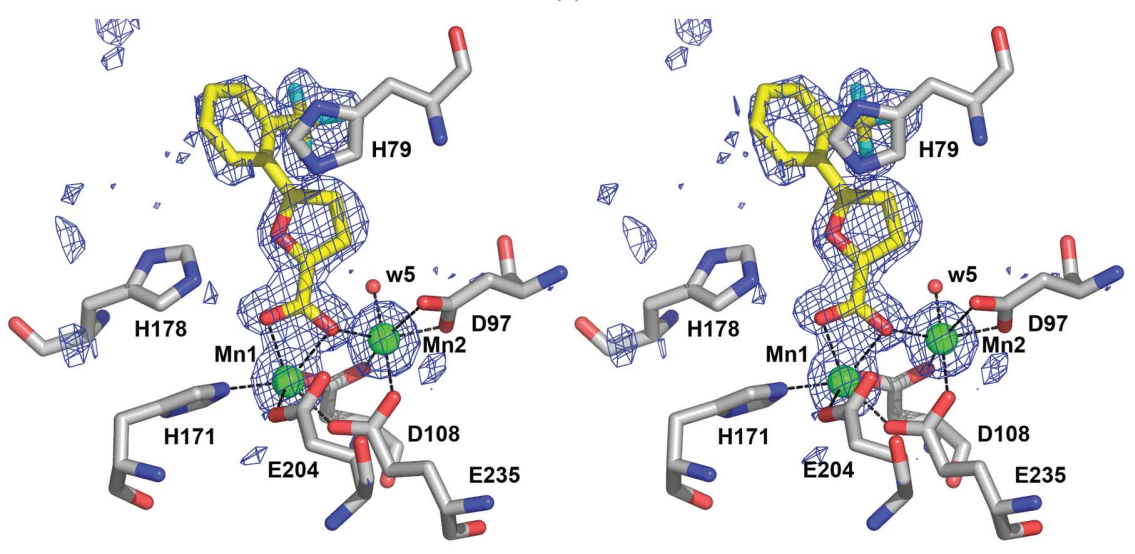

(b)

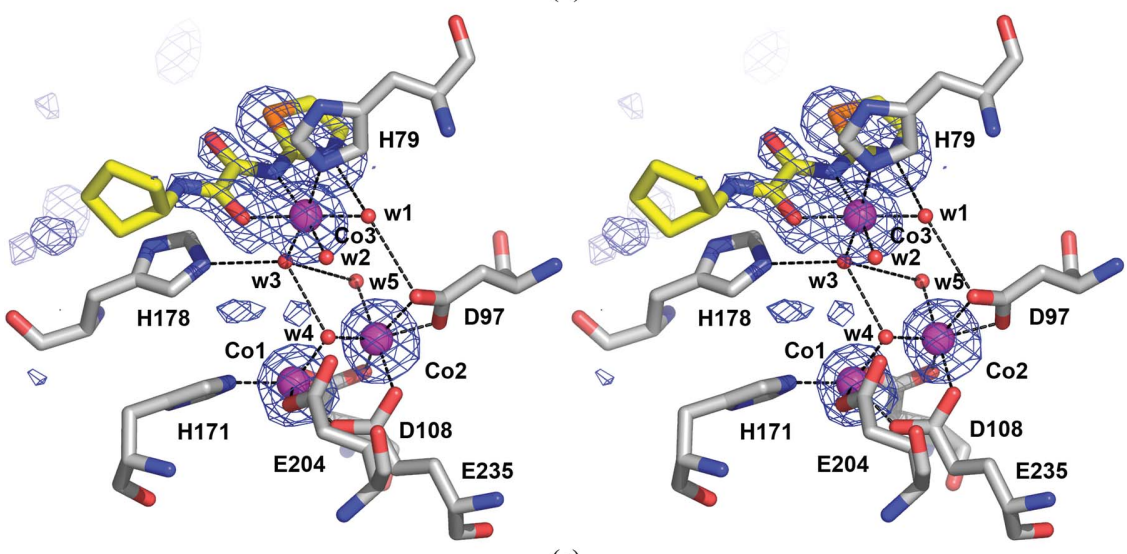

(c)

Figure 4

Stereoviews of inhibitors (2), (3) and (4) at the enzyme active site. Unbiased $F_{\text {obs }}-F_{\text {calc }}$ electron-density maps showing the inhibitors and metal ions are contoured at $3 \sigma$. (a) The $\mathrm{Mn}^{\mathrm{II}}$-form selective inhibitor (2) with the $\mathrm{Mn}^{\mathrm{II}}$-form enzyme. (b) The $\mathrm{Mn}^{\mathrm{II}}$-form selective inhibitor (3) with the $\mathrm{Mn}^{\mathrm{II}}$-form enzyme. (c) The $\mathrm{Co}^{\mathrm{II}}$-form selective inhibitor (4) with the $\mathrm{Co}^{\mathrm{II}}$-form enzyme. For clarity, only the five conserved residues forming the common dinuclear metal site (Asp97, Asp108, His171, Glu204 and Glu235) plus His79 and His178 are shown. Protein residues are colored grey for carbon, red for oxygen and blue for nitrogen. Inhibitors are colored the same way, except that carbons are yellow, sulfurs orange, chlorines green and fluorines cyan. $\mathrm{Mn}^{\mathrm{II}}$ ions are shown as green spheres, while $\mathrm{Co}^{\mathrm{II}}$ ions are shown as magenta spheres. Water molecules are shown as smaller red spheres. Hydrogen bonds and metal interactions are shown as black dashed lines. 
Table 2

Comparison of metal-ligand distances $(\AA)$ in the $\mathrm{Co}^{\mathrm{II}}$ and $\mathrm{Mn}^{\mathrm{II}}$ forms of E. coli MetAP.

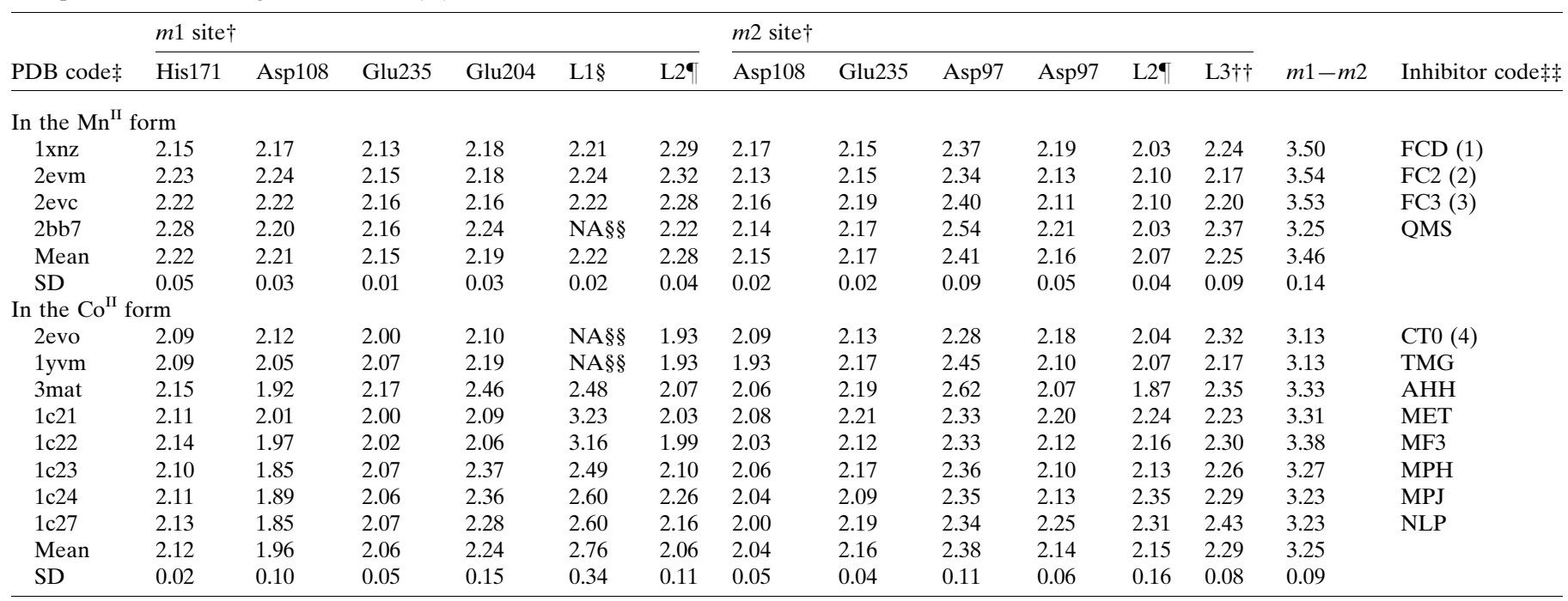

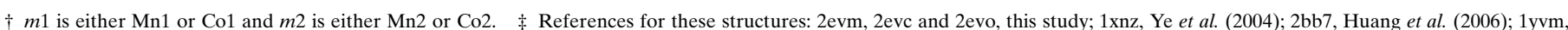

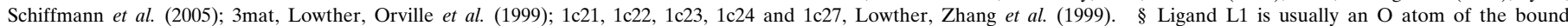

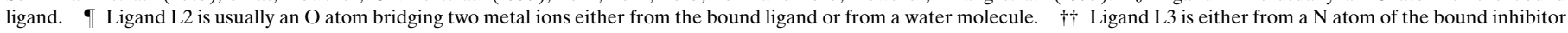

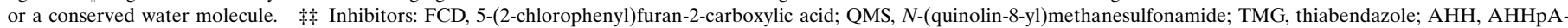

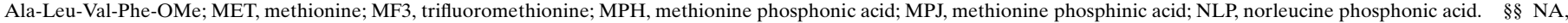
not available because no ligand is found at this position and $\mathrm{Co} 1$ is pentacoordinate.

coordination interactions of (4) with $\mathrm{Co} 3$, the thiazole moiety of (4), which is coplanar with the oxalamide core, also occupies part of the $\mathrm{S}_{1}$ subsite, a hydrophobic pocket formed by residues Cys59, Tyr62, Tyr65, Cys70, Phe177 and Trp221. Finally, the cyclopentyl group of (4) is situated at the mouth of the substrate-binding pocket, where it is exposed to solvent water. This latter hydrophobic interaction may explain the differential binding and inhibitory activity of various analogs of (4) that have different groups in place of the cyclopentyl moiety (Ye et al., 2004).

\subsection{Comparison of different metalloforms of MetAP}

Currently available structures of MetAP are primarily those of $\mathrm{Co}^{\mathrm{II}}$ enzymes, although several structures of the $\mathrm{Mn}^{\mathrm{II}}$ form (PDB codes $1 \mathrm{xnz}, 1 \mathrm{wkm}, 1 \mathrm{r} 5 \mathrm{~h}, 1 \mathrm{r} 5 \mathrm{~g}, 1 \mathrm{r} 58$ ) or the $\mathrm{Zn}^{\mathrm{II}}$ form (PDB codes $1 \mathrm{kq} 9,1 \mathrm{kq} 0$ ) have appeared recently in the literature (Ye et al., 2004; Copik et al., 2005; Sheppard et al., 2004) and in the PDB. Structural information for a broader range of MetAP metalloforms is vital for understanding metalloform-selective inhibition as observed in vitro and for developing active site-directed inhibitors (i.e. metal-directed ligands) that are effective in vivo. To test the hypothesis that discrimination between $\mathrm{Co}^{\mathrm{II}}$ and $\mathrm{Mn}^{\mathrm{II}}$ metalloforms by ligands could be related to different coordination geometries around metal ions $m 1$ and $m 2$, we have compared the relevant metalligand distances in these structures and others currently available in the $\mathrm{Mn}^{\mathrm{II}}$ and $\mathrm{Co}^{\mathrm{II}}$ forms (Table 2). These comparisons are necessarily approximate because of differences in the resolution of the various crystal structures considered. However, it is clear that there are no major changes in metal coordination among various complexes in the $\mathrm{Mn}^{\mathrm{II}}$ form or among various MetAPs in the $\mathrm{Co}^{\mathrm{II}}$ form. At least for MetAPs in the $\mathrm{Mn}^{\mathrm{II}}$ form, the metal-donor distances are consistent with many other $\mathrm{Mn}^{\mathrm{II}}$ metalloenzymes in the literature (Harding, 2001). On the other hand, there seems to be a significant difference in the $m 1-m 2$ distance between the two metalloforms, with the $\mathrm{Mn}-\mathrm{Mn}$ distance being about $8 \%$ longer than the corresponding $\mathrm{Co}-\mathrm{Co}$ distance. Although it is not clear whether this difference will hold up as more examples become known, it is important to relate this directly to the ability of simple ligands to discriminate strongly between MetAPs in the $\mathrm{Mn}^{\mathrm{II}}$ form and in the $\mathrm{Co}^{\mathrm{II}}$ form.

\section{Discussion}

As an exoproteinase, MetAP has a hydrophobic substratebinding pocket that is sized to accommodate the N-terminal methionine residue of nascent proteins for processing. As shown in previous X-ray structures, two metal ions are situated deep in the active-site pocket (Lowther \& Matthews, 2000) and it has been proposed that the metal ions directly participate in the peptide-bond cleavage by activating a water molecule and orienting the substrate in a productive conformation (Lowther \& Matthews, 2002). Any blockage of entry of a MetAP substrate will prevent the hydrolysis of the substrate. For example, fumagillin, as well as its analogs TNP470 and ovalicin, forms a covalent bond with the conserved His178 and completely inhibits the enzyme by preventing substrate access (Liu et al., 1998; Lowther et al., 1998). Both the $\mathrm{Mn}^{\mathrm{II}}$-form and $\mathrm{Co}^{\mathrm{II}}$-form selective inhibitors described here also occupy the substrate-binding pocket, although only the $\mathrm{Mn}^{\mathrm{II}}$-form selective inhibitors actually ligate directly to the catalytic metal ions. $\mathrm{Mn}^{\mathrm{II}}$-form selective inhibitors chelate with both metal 
ions at the dinuclear metal site, while the $\mathrm{Co}^{\mathrm{II}}$-form selective inhibitors recruit a third metal ion, forming a trimetallic enzyme-metal-inhibitor complex. Thus, each of the two classes, those that interact directly with the catalytic metals and those that recruit a third metal to fill the substrate-binding site, takes advantage of strong interactions with metal ions to be able to block the active-site pocket. Although the potency of each inhibitor can be understood in terms of the collected hydrophobic and ligand-metal interactions seen in the crystal structures, the important question that remains is why some inhibitors are so selective for different metalloforms while other ligands are not.

One way to view the interaction of the $\mathrm{Co}^{\mathrm{II}}$ form-selective inhibitor (4) with the $\mathrm{Co}^{\mathrm{II}}$ form of MetAP, at least formally, is that it is the 1:1 complex of (4) with $\mathrm{Co}^{\mathrm{II}}$, preformed in solution, that binds to the enzyme through a combination of Lewis acid-base coordination, hydrogen bonding and hydrophobic interactions. Taking the formalized view that it is the metal complex of (4) binding as a 'hydrophobic Lewis acid' to the typical doubly metalated form of MetAP, rather than (4) binding to a trimetalated form of MetAP (that probably does not exist in solution), provides a simple explanation of the selectivity of (4) for inhibition of $\mathrm{Co}^{\mathrm{II}}$-MetAP over $\mathrm{Mn}^{\mathrm{II}}$ MetAP. It is well documented that N,O-donor ligands such as (4) coordinate much more strongly with softer $\mathrm{CO}^{\mathrm{II}}$ ions than with relatively hard $\mathrm{Mn}^{\mathrm{II}}$ ions. Thus, an important factor in the $\mathrm{Co}^{\mathrm{II}}$-MetAP selectivity of (4) compared with the $\mathrm{Mn}^{\mathrm{II}}$-MetAP selectivity of inhibitors such as (1)-(3) is very likely to be the much greater preference of $\mathrm{Co}^{\mathrm{II}}$ for soft versus hard (i.e. $\mathrm{N}$ versus O) donor ligands (Hanzlik, 1976; Sigel \& McCormick, 1970). We believe this explains why inhibitor (4) is so selective for the $\mathrm{Co}^{\mathrm{II}}$ form of MetAP. It shows no significant activity against the $\mathrm{Mn}^{\mathrm{II}}$ form of MetAP and no crystals of its complex with the $\mathrm{Mn}^{\mathrm{II}}$ form could be obtained.

The binding of a third metal ion very close to the 'classical' MetAP dimetallic site has only recently been observed. Douangamath et al. (2004) first reported a third $\mathrm{Co}^{\mathrm{II}}$ ion bound to Staphylococcus aureus MetAP in the presence of pyridine- or thiazole-containing methionine derivatives; in this case His178 was the only point of direct interaction between the third metal ion and an enzyme residue. More recently, inhibitors such as thiabendazole (Schiffmann et al., 2005) and quinolinyl sulfonamide (Huang et al., 2006) were found to bind with a third $\mathrm{Co}^{\mathrm{II}}$ or $\mathrm{Mn}^{\mathrm{II}}$ ion to E. coli MetAP by coordinating to residue His79 instead of His178. This latter mode of binding is exactly what we see in our $\mathrm{Co}^{\mathrm{II}}$-form structure with (4). Both His79 and His178 are conserved in all MetAPs; thus, this recruitment of a third metal could conceivably also occur with other MetAPs as well and could be a common mechanism of inhibition for many $\mathrm{N}, \mathrm{N}$ - or O,N-donor MetAP inhibitors that have been discovered using an in vitro assay with a high concentration of $\mathrm{Co}^{\mathrm{II}}$ ion.

The reason for the superb selectivity of ligands (1)-(3) for $\mathrm{Mn}^{\mathrm{II}}$-MetAP versus other metalloforms is not entirely clear but is probably also related largely to the hard/soft preferences of $\mathrm{Mn}^{\mathrm{II}}$ for ligands. Thus, phenylfuran carboxylates such as (1)-(3) containing only hard O-donor atoms should make better ligands for $\mathrm{Mn}^{\mathrm{II}}$ than for $\mathrm{Co}^{\mathrm{II}}$. Comparing the relevant metal-ligand distances has revealed some subtle potential differences between the $\mathrm{Co}^{\mathrm{II}}$ and $\mathrm{Mn}^{\mathrm{II}}$ forms. However, the importance of these differences in determining the metalloform selectivity will certainly need further evaluation. Leaving the phenylfuran carboxylate core intact, modification of other substituents on the $\mathrm{Mn}^{\mathrm{II}}$-form selective inhibitors resulted in parallel shifts in inhibitory potencies among the different metalloforms (Huang et al., 2005), indicating that the interaction of the carboxylate group with the metals at the dinuclear site is a major determinant in the metalloform selectivity. The specific distance between the two coordinating carboxyl $\mathrm{O}$ atoms and their specific approach to the metal ions may uniquely satisfy the requirement for coordinating with the $\mathrm{Mn}^{\mathrm{II}}$ ions and make compounds such as (1)-(3) very selective for the $\mathrm{Mn}^{\mathrm{II}}$ form of MetAP. $\mathrm{Mn}^{\mathrm{II}}$ ions are suggested to be the in vivo metal for human type II MetAP (Wang et al., 2003) and could also be the in vivo metal for other MetAPs. Although we do not fully understand the mechanisms governing the metalation of apo-MetAP in cells, the $\mathrm{Mn}^{\mathrm{II}}$ form selective inhibitors we have obtained from highthroughput screening, along with other inhibitors with different selectivity profiles, will be useful tools in defining which metalloforms of MetAP are important under physiological conditions in living cells.

In summary, structural analysis of the complexes of E. coli MetAP with the $\mathrm{Mn}^{\mathrm{II}}$-form and $\mathrm{Co}^{\mathrm{II}}$-form selective inhibitors have provided insights into the structural basis of their metalloform selectivity. The unexpected unique binding mode of the $\mathrm{Co}^{\mathrm{II}}$-form selective inhibitor (4) is consistent with its high potency and selectivity profile. Its high selectivity towards the $\mathrm{Co}^{\mathrm{II}}$-form of the enzyme is explained, at least in part, by its excellent capability of coordinating with soft $\mathrm{Co}^{\mathrm{II}}$ ions. The superb selectivity of the $\mathrm{Mn}^{\mathrm{II}}$-form selective inhibitors (1)-(3) is not entirely understood, but may be related to their unique coordination with the $\mathrm{Mn}^{\mathrm{II}}$ ions at the dinuclear site using the carboxylate group.

This research was supported by NIH grants AI065898, RR015563 and RR016475. The High Throughput Screening Laboratory and the Protein Structure Laboratory were supported by NIH grants RR015563 and RR017708 from the COBRE program of the National Center for Research Resources, the University of Kansas and the Kansas Technology Enterprise Corporation.

\section{References}

Arfin, S. M., Kendall, R. L., Hall, L., Weaver, L. H., Stewart, A. E., Matthews, B. W. \& Bradshaw, R. A. (1995). Proc. Natl Acad. Sci. USA, 92, 7714-7718.

Bradshaw, R. A., Brickey, W. W. \& Walker, K. W. (1998). Trends Biochem. Sci. 23, 263-267.

Brünger, A. T., Adams, P. D., Clore, G. M., DeLano, W. L., Gros, P., Grosse-Kunstleve, R. W., Jiang, J.-S., Kuszewski, J., Nilges, M., Pannu, N. S., Read, R. J., Rice, L. M., Simonson, T. \& Warren, G. L. (1998). Acta Cryst. D54, 905-921.

Chang, S. Y., McGary, E. C. \& Chang, S. (1989). J. Bacteriol. 171, 4071-4072. 
Collaborative Computational Project, Number 4 (1994). Acta Cryst. D50, 760-763.

Copik, A. J., Nocek, B. P., Swierczek, S. I., Ruebush, S., Jang, S. B., Meng, L., D'Souza, V. M., Peters, J. W., Bennett, B. \& Holz, R. C. (2005). Biochemistry, 44, 121-129.

D'Souza, V. M., Bennett, B., Copik, A. J. \& Holz, R. C. (2000). Biochemistry, 39, 3817-3826.

D’Souza, V. M. \& Holz, R. C. (1999). Biochemistry, 38, 11079 11085.

DeLano, W. L. (2002). The PyMOL Molecular Visualization System. http://www.pymol.org.

Douangamath, A., Dale, G. E., D’Arcy, A., Almstetter, M., Eckl, R., Frutos-Hoener, A., Henkel, B., Illgen, K., Nerdinger, S., Schulz, H., Mac Sweeney, A., Thormann, M., Treml, A., Pierau, S., Wadman, S. \& Oefner, C. (2004). J. Med. Chem. 47, 1325-1328.

Garrabrant, T., Tuman, R. W., Ludovici, D., Tominovich, R., Simoneaux, R. L., Galemmo, R. A. Jr \& Johnson, D. L. (2004). Angiogenesis, 7, 91-96.

Griffith, E. C., Su, Z., Niwayama, S., Ramsay, C. A., Chang, Y. H. \& Liu, J. O. (1998). Proc. Natl Acad. Sci. USA, 95, 15183-15188.

Griffith, E. C., Su, Z., Turk, B. E., Chen, S., Chang, Y. H., Wu, Z., Biemann, K. \& Liu, J. O. (1997). Chem. Biol. 4, 461-471.

Hanzlik, R. P. (1976). Inorganic Aspects of Biological and Organic Chemistry. New York: Academic Press.

Harding, M. M. (2001). Acta Cryst. D57, 401-411.

Huang, M., Xie, S.-X., Ma, Z.-Q., Hanzlik, R. P. \& Ye, Q.-Z. (2006). Biochem. Biophys. Res. Commun. 339, 506-513.

Huang, Q. Q., Huang, M., Nan, F. J. \& Ye, Q. Z. (2005). Bioorg. Med. Chem. Lett. 15, 5386-5391.

Jones, T. A., Zou, J. Y., Cowan, S. W. \& Kjeldgaard, M. (1991). Acta Cryst. A47, 110-119.

Kabsch, W. (1993). J. Appl. Cryst. 26, 795-800.

Keding, S. J., Dales, N. A., Lim, S., Beauliu, D. \& Rich, D. H. (1998). Synth. Commun. 28, 4463-4470.

Laskowski, R. A., MacArthur, M. W., Moss, D. S. \& Thornton, J. M. (1993). J. Appl. Cryst. 26, 283-291.

Leroux, F. (2004). Chembiochem, 5, 644-649.

Li, J. Y., Chen, L. L., Cui, Y. M., Luo, Q. L., Li, J., Nan, F. J. \& Ye, Q. Z. (2003). Biochem. Biophys. Res. Commun. 307, 172-179.
Liu, S., Widom, J., Kemp, C. W., Crews, C. M. \& Clardy, J. (1998). Science, 282, 1324-1327.

Lowther, W. T., McMillen, D. A., Orville, A. M. \& Matthews, B. W. (1998). Proc. Natl Acad. Sci. USA, 95, 12153-12157.

Lowther, W. T. \& Matthews, B. W. (2000). Biochim. Biophys. Acta, 1477, 157-167.

Lowther, W. T. \& Matthews, B. W. (2002). Chem. Rev. 102, 4581-4608.

Lowther, W. T., Orville, A. M., Madden, D. T., Lim, S., Rich, D. H. \& Matthews, B. W. (1999). Biochemistry, 38, 7678-7688.

Lowther, W. T., Zhang, Y., Sampson, P. B., Honek, J. F. \& Matthews, B. W. (1999). Biochemistry, 38, 14810-14819.

Miller, C. G., Kukral, A. M., Miller, J. L. \& Movva, N. R. (1989). J. Bacteriol. 171, 5215-5217.

Oefner, C., Douangamath, A., D'Arcy, A., Hafeli, S., Mareque, D., Mac Sweeney, A., Padilla, J., Pierau, S., Schulz, H., Thormann, M., Wadman, S. \& Dale, G. E. (2003). J. Mol. Biol. 332, 13-21.

Roderick, S. L. \& Matthews, B. W. (1993). Biochemistry, 32, 39073912.

Schiffmann, R., Heine, A., Klebe, G. \& Klein, C. D. (2005). Angew. Chem. Int. Ed. Engl. 44, 3620-3623.

Sheppard, G. S., Wang, J., Kawai, M., BaMaung, N. Y., Craig, R. A., Erickson, S. A., Lynch, L., Patel, J., Yang, F., Searle, X. B., Lou, P., Park, C., Kim, K. H., Henkin, J. \& Lesniewski, R. (2004). Bioorg. Med. Chem. Lett. 14, 865-868.

Sigel, H. \& McCormick, D. B. (1970). Acc. Chem. Res. 3, 201-208.

Sin, N., Meng, L., Wang, M. Q., Wen, J. J., Bornmann, W. G. \& Crews, C. M. (1997). Proc. Natl Acad. Sci. USA, 94, 6099-6103.

Towbin, H., Bair, K. W., DeCaprio, J. A., Eck, M. J., Kim, S., Kinder, F. R., Morollo, A., Mueller, D. R., Schindler, P., Song, H. K., van Oostrum, J., Versace, R. W., Voshol, H., Wood, J., Zabludoff, S. \& Phillips, P. E. (2003). J. Biol. Chem. 278, 52964-52971.

Vaughan, M. D., Sampson, P. B. \& Honek, J. F. (2002). Curr. Med. Chem. 9, 385-409.

Walker, K. W. \& Bradshaw, R. A. (1998). Protein Sci. 7, 2684-2687.

Wang, J., Sheppard, G. S., Lou, P., Kawai, M., Park, C., Egan, D. A., Schneider, A., Bouska, J., Lesniewski, R. \& Henkin, J. (2003). Biochemistry, 42, 5035-5042.

Ye, Q. Z., Xie, S. X., Huang, M., Huang, W. J., Lu, J. P. \& Ma, Z. Q. (2004). J. Am. Chem. Soc. 126, 13940-13941. 